\title{
Isolasi bakteri resisten merkuri dalam urin pasien dengan tumpatan amalgam di Puskesmas Bahu Manado
}

\author{
Debora Kambey ${ }^{1}$ \\ Fatimawali $^{2}$ \\ Aaltje E. Manampiring ${ }^{2}$ \\ ${ }^{1}$ Kandidat Skripsi Fakultas Kedokteran Universitas Sam Ratulangi Manado
${ }^{2}$ Bagian Kimia Fakultas Kedokteran Universitas Sam Ratulangi Manado
Email: dfkambey@gmail.com
}

\begin{abstract}
Tooth damage is the main health problem in most of countries. Amalgam is an excellent dental restorative material which has been used in dentistry for 150 years. It consists of liquid mercury and other metal element. The toxic mercury vapor can be released from dental amalgam and then be absorbed and accumulated in tissues and organs. Bacteria in the body of patients with amalgam fillings are exposed by mercury continuously and become resistant. Bacteria detoxify mercury through mer gene (mercuric ion reductase) reduces the toxic mercury ion $\left(\mathrm{Hg}^{2+)}\right.$ into mercury element $\left(\mathrm{Hg}^{0}\right)$. This study was aimed to know the present of mercury-resistant bacteria and its types in the urine of patients with amalgam fillings at Puskesmas Bahu Manado. Samples were 2 urine samples from patients with amalgam fillings of $\geq 6$ months at the Dental Clinic of Puskesmas Bahu Manado. This was a descriptive exploratory study. The result showed that bacteria colonies grew in the medium with 3 different concentrations of mercury as follows: $10 \mathrm{ppm}, 20 \mathrm{ppm}$ and $40 \mathrm{ppm}$ of $\mathrm{HgCl}_{2}$. There were 4 genus of bacteria identified through morphology, physiology and biochemistry tests: Bacillus, Escherichia, Streptococcus and Staphylococcus. Conclusion: There were mercury-resistant bacteria of genus Bacillus, Escherechia, Streptococcus, and Staphylococcus in the urine of patients with amalgam fillings at Puskesmas Bahu Manado.
\end{abstract}

Keywords: Mercury-resistant bacteria, amalgam, urine.

\begin{abstract}
Abstrak: Kerusakan gigi merupakan masalah kesehatan utama pada sebagian besar Negara. Amalgam merupakan bahan restoratif gigi yang unggul dan telah digunakan dalam kedokteran gigi selama 150 tahun. Amalgam terdiri dari cairan merkuri dan logam lain. Merkuri yang toksik melalui uap merkuri bisa terlepas dari amalgam gigi kemudian diabsorbsi dan diakumulasi dalam jaringan dan organ. Bakteri pada tubuh pasien tumpatan amalgam yang mengalami paparan merkuri bisa menjadi resisten terhadap merkuri. Bakteri mendetoksifikasi merkuri melalui gen mer (mercuric ion reductase) dengan mereduksi ion merkuri beracun $\left(\mathrm{Hg}^{2+}\right)$ menjadi unsur merkuri $\left(\mathrm{Hg}^{\circ}\right)$. Penelitian ini bertujuan untuk mengetahui adanya bakteri resisten merkuri pada urin pasien dengan tumpatan amalgam dan jenisnya di Puskesmas Bahu Manado. Sampel ialah 2 sampel urin dari pasien tumpatan amalgam di Poli Gigi Puskesmas Bahu Manado yang telah menggunakan tumpatan amalgam selama 6 bulan atau lebih. Jenis penelitian ialah deskriptif eksploratif. Hasil penelitian menunjukkan bahwa terdapat pertumbuhan koloni bakteri pada media dengan konsentrasi $\mathrm{HgCl}_{2} 10 \mathrm{ppm}, 20 \mathrm{ppm}$ dan 40 ppm. Terdapat 4 genus bakteri yang diidentifikasi melalui uji morfologi, fisiologi, dan biokimia yaitu: Bacillus, Escherichia, Streptococcus, dan Staphylococcus. Simpulan: Terdapat bakteri resisten merkuri dari genus Bacillus, Staphylococcus, Escherichia, dan Streptococcus dalam urin pasien dengan tumpatan amalgam di Puskesmas Bahu Manado.
\end{abstract}

Kata Kunci: Bakteri resisten merkuri, amalgam, urin 
Prevalensi kerusakan gigi pada sebagian besar Negara berpenghasilan rendah dan menengah meningkat seiring dengan berubahnya gaya hidup, konsumsi gula yang berlebihan, kebutuhan fluorida yang tidak mencukupi, serta kurangnya program pencegahan penyakit gigi dan mulut. Kerusakan gigi juga masih menjadi masalah kesehatan utama di sebagian besar negara berpenghasilan tinggi dimana penyakit ini mempengaruhi $60-90 \%$ anak usia sekolah dan sebagian besar orang dewasa. ${ }^{1}$

Amalgam menjadi bahan restoratif gigi pilihan yang unggul, serbaguna dan telah digunakan dalam ilmu kedokteran gigi selama kurang lebih 150 tahun. Selain itu, amalgam merupakan bahan tambalan gigi yang kuat, tahan lama, murah dan mudah untuk diaplikasikan. ${ }^{2}$ Meskipun ada bukti penurunan penggunaannya di dunia, amalgam masih digunakan oleh dokter gigi sebagai pilihan pertama untuk memperbaiki gigi posterior. ${ }^{3}$

Amalgam terdiri dari cairan merkuri dan campuran logam lain seperti perak, tembaga, timah dan seng. ${ }^{3}$ Unsur yang menjadi perhatian ketika berbicara tentang resiko penggunaan amalgam gigi adalah merkuri. Hal ini didukung dengan urutan toksisitas logam dari yang paling toksik terhadap manusia yaitu: $\mathrm{Hg}^{2+}>\mathrm{Cd}^{2+}>\mathrm{Ag}^{2+}>\mathrm{Ni}$ ${ }^{2+}>\mathrm{Pb}^{2+}>\mathrm{As}^{2+}>\mathrm{Cr}^{2+}>\mathrm{Sn}^{2+}>\mathrm{Zn}^{2+}$. 4,5

Penggunaan merkuri dalam ilmu kedokteran gigi telah menghasilkan sejumlah kontroversi sejak pertengahan abad ke-19 kemudian meningkat drastis dalam 25 tahun terakhir. Hal ini disebabkan oleh munculnya suatu analisis yang menunjukkan bahwa merkuri bisa terlepas dari amalgam gigi. ${ }^{6}$ Melalui suatu penelitian yang dilakukan pada hewan, didapatkan bahwa uap merkuri secara terus menerus dilepaskan dari amalgam gigi kemudian diabsorbsi dan diakumulasi di dalam jaringan dan organ. Banyaknya uap merkuri yang terlepas dipengaruhi oleh berbagai faktor antara lain, ukuran tumpatan, permukaan gigi, cara mengunyah makanan, cara menggosok gigi, tekstur makanan, komposisi amalgam dan lama pemakaiannya. Pada pasien tumpatan amalgam, kadar merkuri dalam darah, jaringan, urin, saliva dan feses ditemukan meningkat. Ditemukan juga bahwa pemakaian amalgam berhubungan dengan akumulasi kadar merkuri pada otak dan ginjal. ${ }^{6}$

Bakteri normal yang ada pada pasien dengan tumpatan amalgam mengalami paparan terus menerus dari merkuri yang berasal dari amalgam. Bakteri berperan utama dalam detoksifikasi merkuri melalui gen mer terutama mer (mercuric ion reductase). Gen mer melindungi bakteri dari senyawa beracun $\mathrm{Hg}^{2+}$ dengan mereduksi ion merkuri $\left(\mathrm{Hg}^{2+}\right)$ menjadi unsur merkuri $\left(\mathrm{Hg}^{\mathrm{O}}\right)$. Hal ini membuat bakteri menjadi resisten terhadap merkuri. Banyaknya gen mer yang dimiliki bakteri dipengaruhi oleh paparan secara terus menerus dari amalgam gigi., ${ }^{7,8,9}$

Ganggola $\mathrm{R}^{10}$ melakukan penelitian melalui sampel urin pasien tumpatan amalgam di poli gigi Puskesmas Bahu Manado pada tahun 2013 dan ditemukan 6 genus bakteri resisten merkuri yang bertahan sampai konsentrasi merkuri 40 ppm, yaitu Alcaligenes, Neisseria, Planococcus, Marinococcus, Streptococcus, dan Morococcus setelah berbagai uji yang dilakukan.

Tujuan penelitian ini adalah mengetahui adanya bakteri resisten merkuri dan mengetahui jenis bakteri resisten merkuri pada urin pasien dengan tumpatan amalgam di Puskesmas Bahu Manado.

\section{METODE PENELITIAN}

Jenis penelitian yang digunakan dalam penelitian ini ialah deskriptif eksploratif. Penelitian ini dilakukan pada bulan September-November 2016 di Puskesmas Bahu dan Laboratorium Farmasi Fakulltas MIPA Universitas Sam Ratulangi. Populasi dalam penelitian adalah bakteri pada urin pasien tumpatan amalgam di Poli Gigi Puskesmas Bahu Manado. Sampel yang 
diambil dalam penelitian ini adalah 2 sampel urin dari pasien tumpatan amalgam di Poli Gigi Puskesmas Bahu Manado yang telah menggunakan tumpatan amalgam selama 6 bulan atau lebih. Variabel penelitian adalah bakteri resisten merkuri.

Pengambilan sampel dilakukan dengan mengambil urin pasien tumpatan amalgam di Puskesmas Bahu Manado menggunakan cara pengambilan urin porsi tengah kemudian urin ditampung di dalam pot penampung. Sampel yang telah didapatkan dari Puskesmas segera dibawa ke laboratorium Mikrobiologi Farmasi FMIPA Universitas Sam Ratulangi dan disimpan ke dalam lemari pendingin yang kemudian akan di kultur dan diidentifikasi.

Prosedur kerja meliputi tahap isolasi dan identifikasi. Tahap Isolasi bertujuan untuk mengisolasi bakteri yang ada pada urin. Tahap identifikasi terdiri dari uji morfologi, uji fisiologi dan uji biokimia. Uji morfologi dilakukan dengan pewarnaan gram yang bertujuan untuk memudahkan melihat bakteri dengan mikroskop, memperjelas ukuran dan bentuk bakteri, melihat struktur luar dan struktur dalam seperti dinding sel dan vakuola, menghasilkan sifat-sifat fisik dan kimia yang khas dari pada bakteri dengan zat warna, serta menentukan bentuk bakteri apakah berupa basil, kokus atau spiral. Uji Motilitas berperan dalam mengetahui pergerakan bakteri. Uji bersifat positif apabila terlihat adanya pertumbuhan melebar koloni dari bekas tusukan jarum ose. Uji Biokimia terdiri atas Uji Fermentasi Karbohidrat, Uji Indol, Uji Katalase, Uji Lisin Dekarboksilase, Uji $\mathrm{H}_{2} \mathrm{~S}$, dan Uji Sitrat.

Uji Fermentasi Karbohidrat bertujuan untuk menentukan kemampuan bakteri dalam mendegradasi dan memfermentasikan karbohidrat tertentu dengan memproduksi asam atau basa dan gas. Pembentukan asam terlihat sebagai perubahan warna substrat karbohidrat dari warna merah menjadi warna kuning. Pembentukan gas biasanya terjadi didasar media ditandai dengan adanya ruang kosong didasar media.

Uji Indol bertujuan untuk mengetahui apakah bakteri mempunyai enzim triptophanase sehingga bakteri tersebut mampu mengoksidasi asam amino triptophan membentuk indol.. Indol positif bila kultur berwarna merah pada saat penambahan reagen.

Uji Katalase bertujuan untuk menentukan kemampuan bakteri untuk mendegradasi hidrogen peroksida melalui produksi enzim katalase. Bila terjadi pembentukan gelembung udara, maka uji ini positif.

Uji Lisin Dekarboksilase bertujuan untuk melihat kemampuan bakteri melakukan dekarboksilasi dalam asam amino berupa lysine melalui produksi enzim dekarboksilase. Uji positif, media berwarna ungu. Uji negatif, warna media tetap.

Uji $\mathrm{H}_{2} \mathrm{~S}$ bertujuan untuk mengetahui terbentuknya Sulfida. Uji positif, terbentuknya warna/ endapan hitam. Uji negatif, tidak terbentuk endapan/ warna hitam.

Uji Sitrat bertujuaan untuk menentukan kemampuan bakteri dalam menggunakan sitrat sebagai sumber karbon dan energi. Uji positif, media berwarna biru. Uji negatif, media tetap berwarna hijau.

\section{HASIL PENELITIAN}

Hasil uji resistensi merkuri dan isolasi bakteri dari semua sampel urin menunjukkan bahwa terdapat pertumbuhan koloni bakteri resisten merkuri pada masing-masing media nutrient agar dengan konsentrasi $\mathrm{HgCl}_{2} 10$ ppm, 20 ppm dan 40 ppm dengan perlakuan I yaitu pengenceran $10^{-1}$ yang memperlihatkan pertumbuhan koloni bakteri yang banyak dan perlakuan II yaitu pengenceran $10^{-2}$ yang memperlihatkan pertumbuhan koloni yang semakin sedikit.

Koloni bakteri resisten merkuri kemudian diamati dan diseleksi jenisnya berdasarkan ciri-ciri dan sifat pertumbuhannya pada media. Didapatkan 
bentuk-bentuk koloni yaitu bulat dengan tepi tegas, bulat dengan tepi halus, oval dan tidak beraturan. Didapatkan pula bahwa pertumbuhan koloni bakteri yang paling banyak berwarna putih keruh dan ada juga yang berwarna biru kehijauan. Setelah diamati dan diseleksi, maka pada sampel A diperoleh pertumbuhan 4 jenis koloni pada konsentrasi $\mathrm{HgCl}_{2} 10$ ppm, 3 jenis koloni pada konsentrasi $\mathrm{HgCl}_{2} 20 \mathrm{ppm}$, dan 5 jenis koloni pada konsentrasi $\mathrm{HgCl}_{2} 40$ ppm. Pada sampel $\mathrm{B}$, diperoleh pertumbuhan 3 jenis koloni pada konsentrasi $\mathrm{HgCl}_{2} 10$ ppm, 3 jenis koloni pada konsentrasi $\mathrm{HgCl}_{2} 20$ ppm, dan 3 jenis koloni pada konsentrasi $\mathrm{HgCl}_{2} 40$ ppm.

Tabel 1. Hasil Uji Resistensi Bakteri Terhadap Merkuri

\begin{tabular}{ccccccc}
\hline & \multicolumn{2}{c}{10 ppm } & \multicolumn{2}{c}{ 20 ppm } & \multicolumn{2}{c}{40 ppm } \\
Kode & I & II & I & II & I & II \\
Isolat & & & & & & \\
\hline A & + & + & + & + & + & + \\
$\mathrm{B}$ & + & + & + & + & + & + \\
\hline
\end{tabular}

Tabel 2. Hasil Isolasi Dan Seleksi Bakteri Resisten Merkuri

\begin{tabular}{|c|c|c|c|}
\hline \multirow[t]{2}{*}{$\begin{array}{l}\text { Kode } \\
\text { Isolat }\end{array}$} & \multicolumn{3}{|c|}{$\begin{array}{c}\text { Jumlah jenis koloni yang tumbuh } \\
\text { pada media dengan konsentrasi } \\
\mathrm{HgCl}_{2}\end{array}$} \\
\hline & $10 \mathrm{ppm}$ & $20 \mathrm{ppm}$ & $40 \mathrm{ppm}$ \\
\hline A & 4 & 3 & 5 \\
\hline B & 3 & 3 & 3 \\
\hline
\end{tabular}

Hasil yang didapatkan pada uji morfologi yaitu pewarnaan gram adalah isolat A.10.1, A.10.4, A.20.1, A.20.2, A.40.3 dan B.20.1 merupakan basil gram positif. Isolat A.10.3, A.20.3, A.40.4, A.40.5, B.10.2, B.10.3, B.20.2, B.40.1, B.40.2 dan B.40.3 merupakan kokus gram positif. Isolat A.10.2, A.40.1, A.40.2, B.20.3 dan B.10.1 merupakan basil gram negatif.

Hasil yang didapatkan dari uji fisiologi atau uji motilitas adalah semua isolat A.10.1,
A.10.2, A.10.3, A.10.4, A.20.1, A.20.2, A.20.3, A.40.1, A.40.2, A.40.3, A.40.4, A.40.5, B.10.1, B.10.2, B.10.3, B.20.1, B.20.2, B.20.3, B.40.1, B.40.2 dan B.40.3 menunjukkan hasil negatif yaitu tidak ada pertumbuhan yang menyebar dari bekas tusukan jarum ose.

Pada uji fermentasi karbohidrat didapatkan hasil sebagai berikut: Isolat A.10.2, A.20.3, A.40.2, dan B.10.3 memberikan perubahan warna pada bagian dasar (butt) menjadi warna kuning sedangkan pada bagian miring (slant) tetap berwarna merah. Terjadi pembentukan gas pada dasar media, sehingga dapat disimpulkan bahwa bakteri pada isolat tersebut tidak dapat memfermentasikan glukosa, sedangkan untuk laktosa dan sukrosa dapat difermentasikan. Isolat A.10.1, A.10.3, A.10.4, A.20.1, A.20.2, A.40.1, A.40.3, A.40.4, A.40.5, B.10.1， B.10.2， B.20.1， B.20.2， B.20.3, B.40.1, B.40.2 dan B.40.3 memberikan perubahan warna pada media menjadi warna kuning baik didaerah butt maupun daerah slant, disertai pembentukan gas didaerah butt, sehingga dapat disimpulkan bahwa bakteri ini dapat memfermentasikan semua jenis karbohidrat dan juga menghasilkan gas $\mathrm{CO}_{2}$ sebagai sisa proses fermentasi.

Pada uji $\mathrm{H}_{2} \mathrm{~S}$ ditemukan bahwa isolat A.20.2, A.40.4 dan B.40.2 membentuk endapan hitam sehingga uji bersifat positif yaitu bakteri mampu membentuk $\mathrm{H}_{2} \mathrm{~S}$. Sedangkan isolat A.10.1, A.10.2, A.10.3, A.10.4, A.20.1, A.20.3, A.40.1, A.40.2, A.40.3, A.40.5, B.10.1, B.10.2, B.10.3, B.20.1, B.20.2, B.20.3, B.40.1 dan B.40.3 tidak membentuk endapan hitam sehingga uji bersifat negatif yaitu bakteri tidak mampu membentuk $\mathrm{H}_{2} \mathrm{~S}$.

Hasil yang diperoleh dari uji indol adalah isolat A.10.2, A.40.1 dan B.40.1 menunjukan hasil positif dengan terbentuknya warna merah seperti cincin di permukaan media ketika media diteteskan reagen covac's. Hal ini menunjukkan bahwa bakteri mempunyai enzim triptofanase yang 
mampu mendegradasi asam amino triptofan membentuk indol dan asam pemuat. Sedangkan isolat A.10.1, A.10.3, A.10.4, A.20.1, A.20.2, A.20.3, A.40.2, A.40.3, A.40.4, A.40.5, B.10.1, B.10.2, B.10.3, B.20.1, B.20.2, B.20.3, B.40.2 dan B.40.3 tidak mengalami perubahan sehingga uji bersifat negatif yaitu bakteri tidak mempunyai enzim triptofanase

Pada uji katalase, semua isolat A.10.1, A.10.2, A.10.3, A.10.4, A.20.1, A.20.2, A.20.3, A.40.1, A.40.2, A.40.3, A.40.4, A.40.5, B.10.1, B.10.2, B.10.3, B.20.1, B.20.2, B.20.3, B.40.1, B.40.2 dan B.40.3 menunjukkan hasil positif yaitu adanya pembentukan gelembung gas pada setiap tabung setelah diteteskan $\mathrm{H}_{2} \mathrm{O}_{2}$ (hidrogen peroksida). Hal ini menunjukkan bahwa bakteri memproduksi enzim katalase yang dapat memecah $\mathrm{H}_{2} \mathrm{O}_{2}$ menjadi $\mathrm{H}_{2} \mathrm{O}$ dan $\mathrm{O}_{2}$.

Pada uji lysine dekarboksilase, isolat A.10.1, A.10.2, A.10.3, A.10.4, A.20.1, A.20.2, A.40.1, A.40.2, A.40.3, A.40.4, A.40.5, B.10.1, B.10.2, B.10.3, B.20.1, B.20.2, B.20.3, B.40.1, B.40.2 dan B.40.3 menunjukkan hasil positif dengan perubahan warna media menjadi berwarna lembayung (ungu). Hal ini berarti bahwa bakteri memiliki kemampuan untuk dekarboksilasi dalam asam amino berupa lysine melalui produksi enzim dekarboksilasi. Sedangkan Isolat B.20.3 menunjukkan hasil negatif karena tidak ada perubahan pada warna media yang berarti bahwa bakteri tidak memiliki kemampuan dekarboksilasi.

Pada uji sitrat, isolat A.10.1, A.10.2, A.10.3, A.10.4, A.20.1, A.20.2, A.20.3, A.40.1, A.40.2, A.40.4, A.40.5, B.10.1, B.10.2，B.10.3，B.20.1，B.20.2，B.20.3, B.40.1, B.40.2 dan B.40.3 menunjukkan perubahan warna media yang semula berwarna hijau menjadi berwarna biru, hal ini menunjukkan bahwa uji bersifat positif yang berarti bahwa bakteri mampu menggunakan sitrat sebagai sumber karbon dan energi. Isolat A.40.3 menunjukkan hasil negatif karena warna media tetap berwarna hijau yang berarti bahwa bakteri tidak mempunyai kemampuan untuk menggunakan sitrat sebagai sumber karbon dan energi.

Selanjutnya setelah diperoleh hasil uji morfologi, uji fisiologi dan uji biokimia dari semua isolat, semua hasil ini digabungkan untuk menentukan bakteri apa yang ada pada masing-masing isolat. Penentuan bakteri dilakukan dengan membandingkan hasil uji yang diperoleh dengan data-data yang terdapat dalam buku Bergey's Manual Determinative of Bacteriology.

Isolat A.10.1, A.10.4, A.20.1, A.20.2, A.40.3 dan B.20.1 menunjukkan gambaran basil gram positif tunggal, berpasangan, dalam bentuk rantai dan filamen, tidak motil dan uji katalase positif. Dari hasil uji yang ada, bakteri yang ada pada isolat-isolat diatas adalah Bacillus sp.

Isolat A.10.3, A.20.3, B.10.3, B.20.2 dan B.40.1 menunjukkan gambaran kokus gram positif. Semua isolat tidak motil. Selain itu didapatkan semua isolat diatas menunjukkan uji katalase positif. Dari hasil uji yang ada, bakteri yang ada pada isolat-isolat diatas adalah Staphylococcus sp.

Isolat A.10.2, A.40.1, A.40.2, B.10.1 dan B.20.3 menunjukkan gambaran basil gram negatif, tidak motil, pada uji fermentasi karbohidrat semua isolat positif memproduksi asam dan gas, isolat A.40.1, B.10.1 dan B.20.3 positif memfermentasi glukosa dan laktosa sedangkan A.10.2 dan A.40.2 positif memproduksi laktosa. Pada Uji $\mathrm{H}_{2} \mathrm{~S}$ semua isolat negatif dan pada uji sitrat semua isolat positif. Untuk uji indol isolat A.10.2 dan A.40.1 positif sedangkan A.40.2, B.10.1 dan B.20.3 negatif. Dari semua hasil uji yang ada, bakteri yang ada pada isolat-isolat diatas adalah Escherichia $s p$.

Isolat A.40.4, A.40.5, B.10.2, B.40.2 dan B.40.3 menunjukkan gambaran kokus gram positif berpasangan dan bentuk rantai, tidak motil, pada uji fermentasi karbohidrat semua isolat positif dan memproduksi asam dan gas. Isolat A.40.4 dan B.40.2 positif pada uji $\mathrm{H}_{2} \mathrm{~S}$ 
sedangkan isolat A.40.5 dan B.40.3 negatif. Dari hasil uji yang ada, bakteri yang ada pada isolat-isolat diatas adalah Streptococcus $s p$.

\section{BAHASAN}

Isolasi merupakan suatu cara untuk memisahkan mikroba dalam hal ini bakteri dari sampel atau alam dan menumbuhkannya dalam media kultur secara in vitro sehingga diperoleh biakan murni. Faktor-faktor yang mempengaruhi hasil kultur mikroba adalah jenis media kultur, sifat mikroba dan metode atau teknik laboratorium. ${ }^{11}$

Berdasarkan penelitian yang telah dilakukan dengan mengambil sampel urin pasien dengan tumpatan amalgam yang ada di poli gigi Puskesmas Bahu Kecamatan Malalayang, hasil isolasi bakteri menunjukkan bahwa terdapat pertumbuhan koloni bakteri resisten merkuri dari sampel tersebut dimana hasil uji resistensi merkuri positif menunjukkan semua isolat tumbuh pada media dengan $\mathrm{HgCl}_{2}$ konsentrasi 10 ppm, 20 ppm dan 40 ppm dengan 2 perlakuan.

Setelah dilakukan isolasi dan uji resistensi bakteri terhadap merkuri, tahap selanjutnya adalah identifikasi bakteri resisten merkuri yang dilakukan melalui hasil uji morfologi, uji fisiologi dan uji biokimia yang telah didapatkan.

Isolat A.10.1, A.10.4, A.20.1, A.20.2, A.40.3 dan B.20.1 memiliki ciri--ciri yang mirip dengan Bacillus sp. yaitu bakteri grampositif yang memiliki bentuk sel batang lurus atau berkelok, tunggal dan berpasangan atau bisa juga dalam bentuk rantai dan filamen. Ukuran sel 1 x 3-4 $\mu \mathrm{m}$. Sebagian besar Bacillus sp. memproduksi katalase, tidak motil, dan merupakan organisme saprofit yang sering dijumpai pada tanah, air, udara dan pada vegetasi. ${ }^{12,13}$

Isolat A.10.3, A.20.3, B.10.3, B.20.2 dan B.40.1 memiliki ciri-ciri yang mirip dengan Staphylococcus sp. yaitu sel sferis berdiameter $0.5-1.5 \mathrm{~mm}$ yang ada dalam bentuk tunggal, berpasangan, tetrad, dalam bentuk rantai pendek (3-4 sel), atau secara khas membentuk tandan anggur ireguler. Dinding sel berisi peptidoglikan dan asam teikoik, tidak berkapsul atau kapsul terbatas. Staphylococcus sp. menghasilkan katalase dan merupakan bakteri anaerob fakultatif bersifat nonmotil dan tidak membentuk spora. Populasi alami berada pada kulit, kelenjar kulit dan membran mukus. ${ }^{12,13}$

Isolat A.40.1, A.40.2 dan B.10.1 memiliki ciri-ciri yang mirip dengan Escherichia sp. yaitu basil gram negatif yang bisa motil dan tidak motil, memfermentasi glukosa maupun laktosa dengan produksi asam dan gas. Pada spesies tertentu dari Escherichia sp. sitrat merupakan sumber karbon dan energi. ${ }^{13}$

Isolat A.40.4, A.40.5, B.10.2, B.40.2 dan B.40.3 memiliki ciri yang mirip dengan Streptococcus $s p$. yaitu bakteri sferis gram positif dengan ciri khas berpasangan atau rantai selama pertumbuhannya. Sebagian besar streptokokus tumbuh pada medium solid sebagai koloni discoid berdiameter 1-2 $\mathrm{mm}$. Sebagian besar spesies memferrmentasi glukosa dan terkadang memproduksi $\mathrm{CO}_{2}$. Beberapa spesies dari Streptococcus sp. merupakan flora normal, sebagian lainnya berkaitan dengan penyakit penting pada manusia. $^{12}$

Hasil uji resistensi merkuri dan hasil identifikasi bakteri menunjukkan bahwa terdapat 4 genus bakteri resisten merkuri yang ada pada sampel urin pasien dengan tumpatan amalgam di Puskesmas Bahu Manado pada tahun 2016 antara lain yaitu, Bacillus sp, Escherichia sp, Streptococcus $s p$, dan Staphylococcus sp. Empat genus bakteri in dapat bertahan hidup sampai konsentrasi $\mathrm{HgCl}_{2} 40$ ppm.

Resistensi bakteri terhadap senyawa merkuri tersebar dengan luas baik pada bakteri gram positif maupun gram negatif. Bakteri memiliki jumlah gen berbeda-beda, bervariasi dan mengakibatkan resistensi pada merkuri meskipun yang paling umum karena 
adanya gen reduktase merkuri (merA) yang mereduksi ion $\mathrm{Hg}^{2+}$ menjadi unsur monoatomik yang kurang beracun $\mathrm{Hg}^{0} \cdot{ }^{14}$

Hasil identifikasi bakteri yang diperoleh hampir semua berbeda dengan hasil penelitian Ganggola $R$ yang juga menggunakan sampel urin pasien tumpatan amalgam di poli gigi Puskesmas Bahu Manado pada tahun 2013 dan menemukan 6 genus bakteri resisten merkuri yang bertahan sampai konsentrasi merkruri 40 ppm, yaitu Alcaligenes sp, Neisseria sp, Planococcus sp, Marinococcus sp, Streptococcus sp, dan Morococcus $s p$.

Bakteri normal pada tubuh manusia bisa berbeda-beda pada tiap individu. Hal ini disebabkan oleh beberapa faktor yang mempengaruhi, antara lain; usia, lokasi geografis, status kesehatan, diet, perilaku seksual, obat-obatan, jenis kelamin, perubahan hormonal dan stres. ${ }^{15}$ Oleh sebab itu, jenis bakteri resisten merkuri pada seorang pasien tumpatan amalgam bisa berbeda dengan pasien yang lain.

\section{SIMPULAN}

Hasil isolasi bakteri dan uji resistensi merkuri dari urin pasien dengan tumpatan amalgam di Puskesmas Bahu Manado menunjukkan bahwa terdapat pertumbuhan koloni bakteri yang resisten terhadap merkuri. Jenis bakteri resisten merkuri yang diidentifikasi adalah Bacillus $s p$, Staphylococcus sp, Escherichia sp, dan Streptococcus sp.

\section{DAFTAR PUSTAKA}

1. Petersen, PE. Future use of materials for dental restoration. Report of the meeting convened at WHO HA; 16-17 november 2009; Geneva, Switzerland. WHO; 2010.

2. Rathore M, Singh A, Pant AV. The dental amalgam toxicity fear: a myth or actually. Toxicol Int. 2012; 19(2):81-8.

3. Bharti R, Kulvinder KW, Aseem P T, Anil C. Dental amalgam: an update. J Conserv Dent. 2010;13:204-6.
4. Widowati W, Sastiono A, Raymond JR. Merkuri (Hg). Efek toksik logam. Yogyakarta: Penerbit ANDI; 2008. h. 17-48.

5. Taut, Christina. Dental amalgam: is this the end. Journal of Irish Dental Association. 2013;59 (6):311-7.

6. Soni R, Bhatnagar A, Vivek R, Singh R, Chaturvedi TP, Singh A. A systematic review on mercury toxicity from dental amalgam fillings and its management strategies. Journal of Scientific Research BHU. 2012;56:81-92.

7. Kepel B, Fatimawali. Penentuan jenis dengan analisis gen 16SrRNA dan uji daya reduksi bakteri resisten merkuri yang diisolasi dari feses pasien dengan tambalan amalgam merkuri di puskesmas bahu manado. Jurnal Kedokteran Yarsi. 2015;23(1):45-5.

8. Anne O. Interactions of human commensal bacteria with amalgam-derived mercury: the science and its implications for infectious disease and neurotoxicology. Athens (GA) Georgia University; 2006.

9. Pundogar, Sittie Rohana D, Bautista, Jing R. and Teves, Franco G. Prevalence of mercury-resistant and antibioticresistant bacteria found in dental amalgam. International Research Journal of Biological Sciences. 2014;3(4):1-3.

10. Ganggola $R$, Fatimawali, Manimpiring AE. Bakteri resisten merkuri pada urin pasien tumpatan amalgam poli gigi puskesmas bahu. Jurnal e-Biomedik (eBM). 2013;1(2): 1033-40.

11. Harti AS. Dasar-dasar mikrobiologi kesehatan. Yogyakarta: Nuha Medika; 2012. h. 109-11.

12. Brooks FS, Carroll KC, Nutel JS, Morse SA, Mietzner TA. Jawetz, melnick \& adelberg mikrobiologi kedokteran. Edisi ke-25. Jakarta: EGC; 2013. h. 173-238.

13. Holt JG, Krieg NR, Sneath PHA, Staley JT, Williams ST. Bergey's manual of determinative bacteriology. $9^{\text {th }}$ edition. USA: 1994.

14. Ojo KK , Tung D, Luis H, Bernardo M, 
Kambey, Fatimawali, Manampiring: Isolasi bakteri resisten merkuri ...

Leitao J, Roberts MC. Gram positive mer-A gene in gram negative oral and urine bacteria. Federation of European Microbiological Societies. 2004;
238:411-16.

15. McFarland LV. Normal flora: diversity and functions. Microbial Ecology in Health and Disease. 2000; 12: 193-207. 
Jurnal e-Biomedik (eBm), Volume 4, Nomor 2, Juli-Desember 2016

Tabel 3. Hasil Uji Morfologi, Uji Fisiologi dan Uji Biokimia

\begin{tabular}{|c|c|c|c|c|c|c|c|c|c|c|c|c|}
\hline \multirow{3}{*}{$\begin{array}{l}\text { Kode } \\
\text { Isolat }\end{array}$} & \multicolumn{2}{|c|}{ Uji Morfologi } & \multicolumn{9}{|c|}{ Uji Fisiologi dan Biokimia } & \multirow{3}{*}{ Hasil Identifikasi } \\
\hline & \multirow[b]{2}{*}{$\begin{array}{c}\text { Bentuk } \\
\text { sel }\end{array}$} & \multirow{2}{*}{$\begin{array}{c}\text { Pewarnaan } \\
\text { Gram }\end{array}$} & \multicolumn{9}{|c|}{ Fermentasi Karbohidrat } & \\
\hline & & & Motilitas & Indol & $\mathrm{H} 2 \mathrm{~S}$ & Gas & Glukosa & $\begin{array}{l}\text { Laktosa/ } \\
\text { Sukrosa }\end{array}$ & Lisin & Sitrat & Katalase & \\
\hline A. 10.1 & Basil & Positif & $(-)$ & $(-)$ & $(-)$ & + & + & + & $(+)$ & $(+)$ & $(+)$ & Bacillus sp \\
\hline A. 10.2 & Basil & Negatif & $(-)$ & $(+)$ & $(-)$ & + & - & + & $(+)$ & $(+)$ & $(+)$ & Escherichia sp \\
\hline A. 10.3 & Kokus & Positif & $(-)$ & $(-)$ & $(-)$ & + & + & + & $(+)$ & $(+)$ & $(+)$ & Staphylococcus sp \\
\hline A. 10.4 & Basil & Positif & $(-)$ & $(-)$ & $(-)$ & + & + & + & $(+)$ & $(+)$ & $(+)$ & Bacillus sp \\
\hline A.20.1 & Basil & Positif & $(-)$ & $(-)$ & $(-)$ & + & + & + & $(+)$ & $(+)$ & $(+)$ & Bacillus sp \\
\hline A. 20.2 & Basil & Positif & $(-)$ & $(-)$ & $(+)$ & + & + & + & $(+)$ & $(+)$ & $(+)$ & Bacillus sp \\
\hline A.20.3 & Kokus & Positif & $(-)$ & $(-)$ & $(-)$ & + & - & + & $(+)$ & $(+)$ & $(+)$ & Staphylococcus sp \\
\hline A. 40.1 & Basil & Negatif & $(-)$ & $(+)$ & $(-)$ & + & + & + & $(+)$ & $(+)$ & $(+)$ & Escherichia sp \\
\hline A. 40.2 & Basil & Negatif & $(-)$ & $(-)$ & $(-)$ & + & - & + & $(+)$ & $(+)$ & $(+)$ & Escherichia $s p$ \\
\hline A. 40.3 & Basil & Positif & $(-)$ & $(-)$ & $(-)$ & + & + & + & $(+)$ & $(-)$ & $(+)$ & Bacillus sp \\
\hline A. 40.4 & Kokus & Positif & $(-)$ & $(-)$ & $(+)$ & + & + & + & $(+)$ & $(+)$ & $(+)$ & Streptococcus sp \\
\hline A. 40.5 & Kokus & Positif & $(-)$ & $(-)$ & $(-)$ & + & + & + & $(+)$ & $(+)$ & $(+)$ & Streptococcus sp \\
\hline B. 10.1 & Basil & Negatif & $(-)$ & $(-)$ & $(-)$ & + & + & + & $(+)$ & $(+)$ & $(+)$ & Escherichia sp \\
\hline B. 10.2 & Kokus & Positif & $(-)$ & $(-)$ & $(-)$ & + & + & + & $(+)$ & $(+)$ & $(+)$ & Streptococcus sp \\
\hline B. 10.3 & Kokus & Positif & $(-)$ & $(-)$ & $(-)$ & + & - & + & $(+)$ & $(+)$ & $(+)$ & Staphylococcus sp \\
\hline B.20.1 & Basil & Positif & $(-)$ & $(-)$ & $(-)$ & + & + & + & $(+)$ & $(+)$ & $(+)$ & Bacillus sp \\
\hline B. 20.2 & Kokus & Positif & $(-)$ & $(-)$ & $(-)$ & + & + & + & $(+)$ & $(+)$ & $(+)$ & Staphylococcus sp \\
\hline B. 20.3 & Basil & Negatif & $(-)$ & $(-)$ & $(-)$ & + & + & + & $(-)$ & $(+)$ & $(+)$ & Escherichia $s p$ \\
\hline B. 40.1 & Kokus & Positif & $(-)$ & $(+)$ & $(-)$ & + & + & + & $(+)$ & $(+)$ & $(+)$ & Staphylococcus sp \\
\hline B. 40.2 & Kokus & Positif & $(-)$ & $(-)$ & $(+)$ & + & + & + & $(+)$ & $(+)$ & $(+)$ & Streptococcus sp \\
\hline B.40.3 & Kokus & Positif & $(-)$ & $(-)$ & $(-)$ & + & + & + & $(+)$ & $(+)$ & $(+)$ & Streptococcus sp \\
\hline
\end{tabular}

